\title{
Intra-urban inequalities and Covid-19: an analysis of social isolation in the city of Porto Alegre
}

Desigualdades intraurbanas e a Covid-19: uma análise do isolamento social no município de Porto Alegre

André Coutinho Augustin [I] Paulo Roberto Rodrigues Soares [II]

\begin{abstract}
The Covid-19 pandemic has revealed territorial inequalities that were already present in Brazilian cities. One way in which these inequalities were expressed was the possibility of staying at home as a form of prevention. Analyzing a social isolation index based on cell phone location data, this paper shows that isolation in the city of Porto Alegre did not happen homogeneously in the territory. Factors such as occupation, income and the HDI for each region of the city are related to the different isolation rates that were found and, consequently, help us to understand the different degrees of exposure to the virus.
\end{abstract}

Keywords: Covid-19; coronavirus; pandemic; social isolation; Porto Alegre.

\section{Resumo}

A pandemia de Covid-19 explicitou desigualdades territoriais já presentes nas cidades brasileiras. Uma das formas de expressão dessas desigualdades foi a possibilidade de ficar em casa para se prevenir. Analisando um índice de isolamento social calculado a partir de dados de localização de telefones celulares, este artigo mostra que o isolamento no município de Porto Alegre não aconteceu de forma homogênea no território. Fatores como a ocupação, a renda e o IDH de cada região da cidade se relacionam com as diferentes taxas de isolamento encontradas $e$, consequentemente, ajudam a entender os diferentes graus de exposição ao vírus.

Palavras-chave: Covid-19; coronavírus; pandemia; isolamento social; Porto Alegre. 


\section{Introduction}

In the year 2020, the world was marked by the beginning of the largest pandemic in decades, the Sars-COV-2 or Covid-19 pandemic. This pandemic can also be considered the first global epidemic tracked in "real-time" in the Internet age. Starting in Wuhan's industrial metropolis in the People's Republic of China, the pandemic has spread rapidly to all continents. In the first six months of 2020, about 500,000 people died worldwide from the new coronavirus, a number that had already doubled by September (Johns Hopkins University, 2020). In Brazil, the first confirmation of Covid-19 occurred on February 26 in a São Paulo resident who had returned from a trip to Italy. By December 31, there were 7.6 million cases and more than 197,000 confirmed deaths (Brasil, 2020).

The pandemic generated a series of economic, social, and even political and cultural impacts throughout the world. The world economy suffered a severe downturn, unemployment increased, and cities had their routines completely altered by social isolation measures and lockdowns. As we live in an unequal society, the pandemic also "distributed" its effects unequally among the different countries, territories, and social classes. This text refers to one of these inequalities.

In the Brazilian case, the pandemic has made explicit the inequality in access to health care, a historical situation worsened in recent years by successive budget cuts. In 2019 alone, Constitutional Amendment 95 (known as the "spending cap amendment") caused a reduction of $\mathrm{R} \$ 20$ billion in federal investment in health, making a budget of $\mathrm{R} \$ 122.6$ billion for the health area (CNS, 2020). With about 70 million clients, private health plans had revenues of $\mathrm{R} \$ 226$ billion in the same year (ANS, 2020). It is important to emphasize that the public health system (SUS) serves 211 million Brazilians because even those who have health plans end up using the SUS for the treatment of diseases that not covered by the plans, especially in highly complex care (the most expensive), as well as vaccination campaigns and other services that the population often does not realize that is part of the health budget, such as the control of health surveillance.

This stark difference in funding, with public health having to offer more services than private health with fewer resources, reflects a deeper social inequality. According to the United Nations, Brazil is the second most concentrated country in the world in terms of income, with $1 \%$ of the population receiving $28.3 \%$ of income (UNDP, 2019, p. 309). Wealth is even more concentrated, with only $0.1 \%$ of the population having ownership of $30 \%$ of declared net assets and goods (Unafisco, 2020). Despite this, a significant portion of private healthcare is not paid for by the income of the richest, but by public resources through mechanisms such as the deduction of medical expenses in the Individual Income Tax, which, in 2017, was responsible for $\mathrm{R} \$ 15.1$ billion of tax waiver (86\% of which was appropriated by the richest $10 \%)$. In that same year, total federal subsidies for private health care were $\mathrm{R} \$ 45.9$ billion, representing $40 \%$ of direct health care spending in the country (Brasil, 2019). 
But the access to public health care is only one expression of health inequality. There are countless others, such as different forms of exposure to risks at work and lack of access to basic sanitation and healthy food. The Covid-19 pandemic has added yet another form of inequality: the right to social distance.

Several studies are showing the importance of social distance in controlling the spread of the virus. Hsiang et al. (2020) show that measures such as school closures and movement restrictions in China, South Korea, Italy, Iran, France, and the United States have prevented or delayed 61 million confirmed cases, which corresponds to approximately 495 million total infections. Aquino et al. (2020, p. 2430), after screening 2,771 articles on Covid-19 published in PubMed and analyzing twenty-one of these, conclude that "[...] there are strong indications that strategies to control the spread of the epidemic are effective when case isolation and contact quarantine are combined with a set of population-wide social distancing measures".

Zhou et al. (2020), in a study with phone location data in the city of Shenzhen in China's Guangdong Province, estimate that a $20 \%$ restriction in mobility can flatten the peak caseload by $33 \%$. This flattening is extended to $66 \%$ with $40 \%$ restriction and $91 \%$ with $60 \%$ mobility restriction. Gao et al. (2020), analyzing the location of 45 million cell phones in the United States, pointed out that social distance is associated with a reduction in Covid-19 rates. In a study for Brazilian capital cities, Marino, Komatsu, and Menezes-Filho (2020) compared to state and municipal distancing decrees, isolation rates, calculated by the location of mobile devices, and Covid-19 cases. The authors conclude that, although isolation follows the same general trend nationwide, local measures have significant effects on increasing isolation and reducing contagion.

Despite the importance of remoteness in preventing the pandemic, not everyone has this right in Brazil. IBGE's PNAD Covid-19 survey shows that remote work ("home office") is a reality only among workers with complete higher education, and even then, for less than half of them. Among workers with complete elementary school education, only $1 \%$ was working remotely in September 2020 , reducing to $0.4 \%$ among no education or incomplete elementary school education workers. Regarding race, remote work was done by $14.3 \%$ of whites and $6.8 \%$ of blacks and mixed race.

These numbers indicate that the different forms of labor market insertion can help to understand the dynamics of social distancing and coronavirus contagion, which does not occur homogeneously, socially, or territorially speaking. However, few studies show these relationships. Most Brazilian research on social withdrawal and its effects on the pandemic shows aggregated results for states or municipalities, which is explained mainly by the lack of data.

On the one hand, data on cases and deaths are insufficient. Besides the underreporting, there is no full disclosure of available information. Also in May, the Ministry of Health removed the ZIP code from the public spreadsheet on hospitalizations for Severe Acute Respiratory Syndrome - Sars (Marino; Mendonça; Foletto; Brito; Rolnik; Santoro, 2020). This prevented the realization of more researches such as the one carried out by the Public Space and the Right to the City Laboratory (Laboratório Espaço Público 
Table 1 - Percentage of employed and not away from work people who worked remotely, by education level

\begin{tabular}{l|c|c|c|c|c}
\hline & May & June & July & August & September \\
\hline No education to incomplete elementary school & 0.6 & 0.4 & 0.5 & 0.5 & 0.4 \\
\hline Complete elementary to incomplete middle school & 1.7 & 1.4 & 1.3 & 1.2 & 1.0 \\
\hline Complete secondary to incomplete higher education & 7.9 & 7.3 & 6.7 & 6.0 & 5.4 \\
\hline Complete higher education or more & 38.3 & 37.3 & 35.0 & 33.6 & 32.3 \\
\hline Total & 13.3 & 12.7 & 11.7 & 11.1 & 10.4 \\
\hline
\end{tabular}

Source: IBGE (2020).

e Direito à Cidade - LabCidade), from USP, which showed the importance of the territorial analysis of the pandemic. By cross-referencing the SARS hospital admissions database with the Origin-Destination Survey and with GPS data from São Paulo buses, it was shown a strong association between the places of residence of SARS inpatients and the areas that concentrate more travel origins of people without higher education and in nonexecutive positions, who use public transportation as the main modal for work-related trips (Marino; Klintowitz; Brito; Rolnik; Santoro; Mendonça, 2020). As there is no longer the availability of a national database, studies like this depend on the dissemination of information by local governments, which does not always happen.

On the other hand, information on social remoteness is also lacking and its main source of data has been the location of mobile phones. In Brazil, the most widely used indicator is the Social Isolation Index that was developed by Inloco company from data on 60 million mobile phones. However, Inloco only publicly divulges the index for the country and states of the federation. The few studies at the municipal level result from agreements between the company and local governments or researchers. An example is a study developed by Natividade et al. (2020), which showed that the Salvador neighborhoods with higher poverty indicators have a lower isolation index.

Based on this broad discussion, this article aims to analyze the Social Isolation Index during the Covid-19 pandemic for different regions of the municipality of Porto Alegre. ${ }^{1}$ For this purpose, we used data provided by Inloco for the Data Committee of the Crisis Cabinet for the Confrontation of the Covid-19 Epidemic (Comitê de Dados do Gabinete de Crise para o Enfrentamento da Epidemia Covid-19) in the State of Rio Grande do Sul, which includes one of the authors of this article. Initially, it will be made some considerations about territorial inequalities in Porto Alegre. Then it will be presented the isolation data for the different areas of the city, crossing it with the socio-spatial typologies of the Metropolis Observatory (Observatório das Metrópoles), with the average income and with the HDI. 


\section{Territorial inequalities in Porto Alegre}

There is evidence that economic inequality influences the risk of Covid-19 infection and death (Demenech; Dumith; Vieira; NeivaSilva, 2020), which is something relevant for a country like Brazil. Despite the common sense of a city in southern Brazil, a region considered to have the lowest social inequalities in the country, Porto Alegre is a very unequal metropolis, since its territory presents sectors with high socioeconomic indicators and considerable quality, as well as large urban peripheries with various social and environmental problems.

The data of the Municipal Human Development Index (HDI-M) (Índice de Desenvolvimento Humano Municipal - IDH-M) presented in Atlas Brazil (2020), for example, point out marked differences between the richest neighborhoods (Moinhos de Vento, Chácara das Pedras, Jardim Isabel, with an HDI-M of 0.958) and the poorest of the city (Sarandi, Humaitá, Restinga, with an HDI-M of 0.593). The most developed ones have "first world" indicators, while the less developed ones are comparable to some of the poorest countries on the planet. These inequalities are manifested in the urban infrastructure, the environmental quality of the spaces, availability, and quality of services (including health services), the accessibility and mobility, which are configured in terms of educational and work opportunities reflecting in the life expectancy of the inhabitants, as pointed out by the HDI-M Longevity data: the best-placed sectors (Bela Vista, Moinhos de Vento, Menino Deus) have an index of 0.952 , while the worst (Restinga, Mario Quintana, Vila Dique) are in the range of 0.763 . Data from the Urban Well-Being Index (Índice de Bem-Estar Urbano - IBEU) of the Metropolis Observatory (Ribeiro; Ribeiro, 2016) confirm this intraurban inequality in the municipality of Porto Alegre, with the indicator ranging from 0.967 in the best-situated area and 0.656 in the least favored one.

In the Metropolitan Region of Porto Alegre (Região Metropolitana de Porto Alegre - RMPA), the evidence of inequality is similar. While the municipality of Porto Alegre presents the best indexes (an HDI-M of 0.805), peripheral municipalities present much lower indexes such as São Jerônimo (0.696), Alvorada (0.699), and Viamão (0.717). In the case of the IBEU, it varies from 0.967 in the best sector (in Porto Alegre) to 0.615 in the worst area (in the municipality of Viamão). Notice that the ten best sectors of the IBEU are located in Porto Alegre, while the ten worst are in Alvorada, Viamão, Gravataí, and Canoas, which are municipalities adjacent to Porto Alegre.

The distribution of social indicators in the territory is also related to labor, since, as Milton Santos (2012, p. 120-121) said, "the division of labor [...] is one of the keys to explaining the distribution, on Earth, of men and activities". One way to observe it is from the socio-spatial typologies developed by the Metropolis Observatory (Mammarella; Pessoa; Ferreira; Tartaruga, 2015). Using data from the Brazilian 2010 Demographic Census, especially the professional occupation, the population is classified into 24 sociooccupational categories. The territories, on the other hand, are divided into socio-spatial typologies, depending on the concentration of each of the categories. Figure 1 shows the 
distribution of typologies in the RMPA. Notice that there are five classifications (upper, middle, workers, popular, and agricultural), and the municipality of Porto Alegre has only three of them.

In Porto Alegre, there is a great predominance of the groups considered middle, as well as a strong presence of the upper groups, which comprise almost all of these sectors in the metropolitan region.
The sectors considered popular occupy the wide peripheral strip of the municipality, overflowing into the neighboring cities of Alvorada, Viamão, Canoas, Eldorado do Sul, and Guaíba.

These inequalities are reflected in the different social behaviors and socioeconomic impacts that the Covid-19 pandemic generated in the municipality of Porto Alegre and its Metropolitan Region as we will see below.

Figure 1 - Socio-spatial typologies in the Metropolitan Region of Porto Alegre - 2010

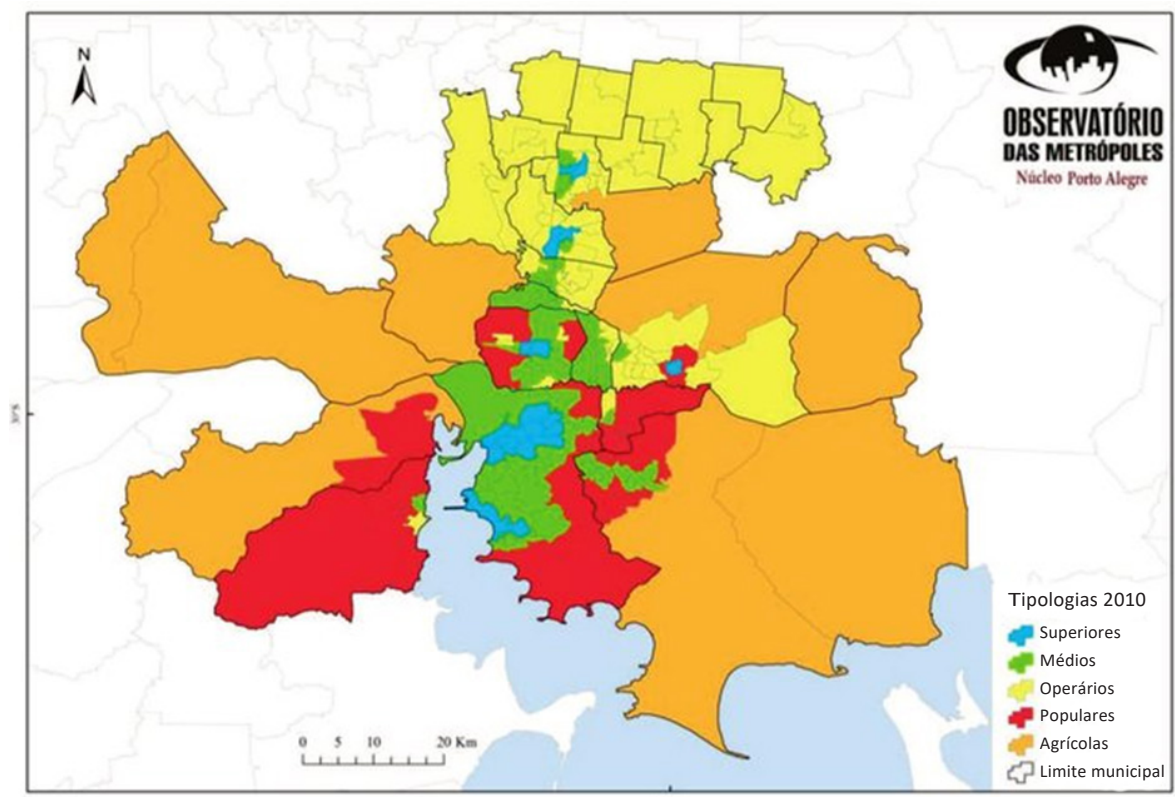

Source: Mammarella et al. (2015, p. 173). 


\section{Index of social isolation in Porto Alegre during the Covid-19 pandemic}

The analysis of the circulation of people in Porto Alegre during the pandemic will be done by using the Social Isolation Index created by Inloco. Through partner applications, the company has access to the location of mobile devices of 60 million users throughout Brazil, 540,000 of which are in Porto Alegre. The index calculation does not identify these users, guaranteeing privacy and anonymity.

To measure isolation, Inloco divides the space into hexagons with a radius of 450 meters. A person is considered to be in isolation if he or she has remained in the same hexagon all day. Those who change their location to another polygon at least once a day are considered to be out of isolation, being counted in the area where they were during the night, in which their residence is supposed to be.

Across Brazil, the isolation trend was similar, with a peak at the end of March and a gradual decline since then. However, the Porto Alegre peak (62\% over the seven-day average) was higher than the Brazilian peak (54\%). The difference, which was being reduced, increased again at the end of June when the cold and rain typical of the Rio Grande do Sul winter climate caused isolation to increase across the state (Rio Grande do Sul, 2020a).

The mean isolation of each city hides large intra-urban differences, however, making it relevant to analyze the index for each city region. To do so, it is necessary to look at the data by a polygon of index calculation. Unlike the municipal isolation, the information by polygon was not available for the whole series, reason why the study was done only for the period from June 7 to October 24, 2020. ${ }^{2}$

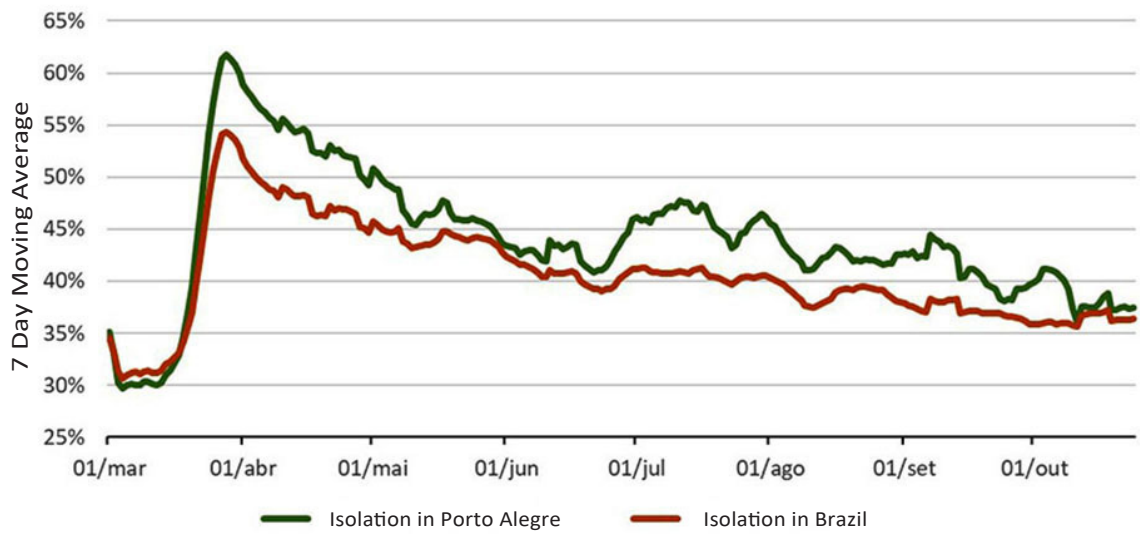


Figure 2 - Social Isolation Index in Porto Alegre

(average value between $6 / 7 / 2020$ and $10 / 24 / 2020$ )

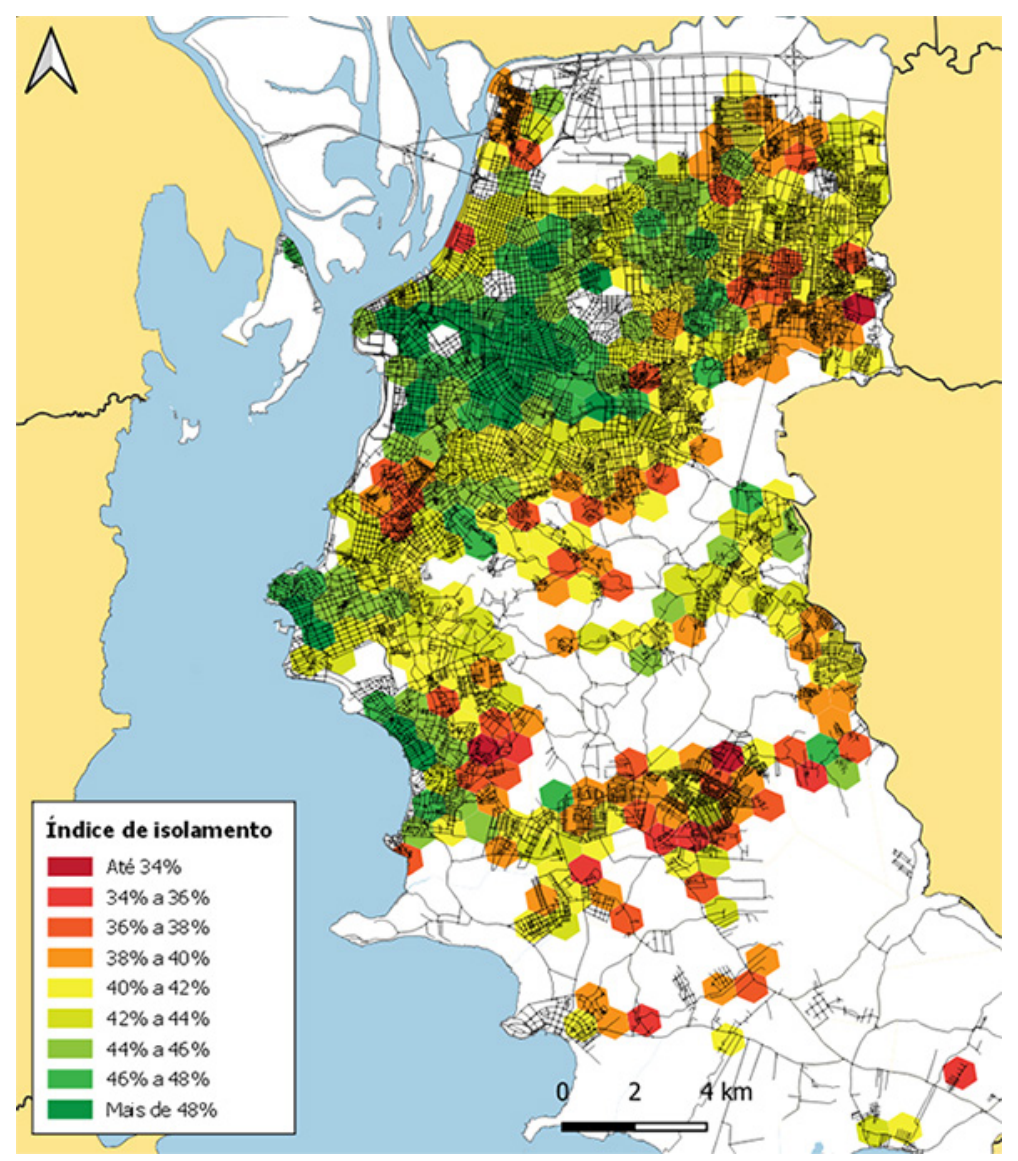

Raw data source: Inloco (2020).

In addition, there were considered only the locations with data available for the entire analysis period. Since a minimum number of connected phones is required to calculate the isolation index for each polygon on the day, some of them do not appear in the base all time. ${ }^{3}$ Considering the 421 polygons in the city of Porto Alegre, 341 had the index for all
139 days analyzed. Figure 2 shows the Social Isolation Index average value in each of these 341 hexagons.

For those who know Porto Alegre, the map already makes it visually clear that the highest levels of isolation occur in the central neighborhoods and some stretches of the Guaíba river front in the South Zone, precisely 
the wealthiest areas of the city. On the other hand, the lower-income regions have lower levels of isolation.

To better explore these spatial differences, we will present the crossings of the Social Isolation Index with three variables, considering the scale available to each one of them:

1) Socio-spatial typologies in the Census weighting areas;

2) Income in the Census tracts;

3) HDI in the municipal Participative Budget regions.

For all three variables, the source of the data is the 2010 Census, which, although outdated, is the only base available at this disaggregation level. ${ }^{4}$

\section{Social isolation index and socio- spatial typologies}

Metropolis Observatory's socio-spatial typologies, already presented, are defined based on the variables of the Census sample questionnaire, which is broader than the general questionnaire. Therefore, they can only be calculated by weighting area, since the census sector, which has a smaller coverage area, does not have sample data released by IBGE.

The territory of Porto Alegre is divided into three typologies: popular, middle, and upper. To calculate the isolation index for each of them, it was made an average of all the Inloco polygons inside the weighting areas classified in that typology. In the case of polygons located on the border between two typologies, the value of their indices entered the average calculation weighted by the intersection area between each of them.

As expected, the "upper" typology areas had the highest isolation (45.3\%) and "popular", the lowest (40.2\%). The difference is larger on weekdays, which suggests a relationship between work and isolation level. Other factors influence the different regions in similar ways. On rainy days, ${ }^{5}$ for example, insulation increased, on average, 5.4 percentage points in the "popular", 5.1 in the "middle" and 5.3 in the "upper" typologies.

During the period of analysis, July presented the greatest isolation in all typologies, which can be explained both by the high number of rainy days and the greater legal

Chart 1 - Socio-spatial typology isolation average

$6 / 7 / 2020$ to $10 / 24 / 2020$

\begin{tabular}{|l|c|c|c|c|}
\hline & $\begin{array}{c}\text { Weekdays } \\
\%\end{array}$ & $\begin{array}{c}\text { Saturdays } \\
\%\end{array}$ & $\begin{array}{c}\text { Sundays and holidays } \\
\%\end{array}$ & $\begin{array}{c}\text { Total } \\
\%\end{array}$ \\
\hline Popular & 36.9 & 42.1 & 52.1 & 40.2 \\
\hline Middle & 38.0 & 43.2 & 53.1 & 41.3 \\
\hline Upper & 42.4 & 47.0 & 56.1 & 45.3 \\
\hline
\end{tabular}

Raw data source: Inloco (2020). 
restrictions on the operation of various sectors of the economy. This month also presented the larger difference in isolation on weekends between the typologies. On working days, the largest difference was found in August, when changes in the state decree that established the "controlled distancing" allowed commerce to open, indicating that the return to work that occurred in this period affected each part of the population differently.

Although these data show inequality in isolation between the regions of each typology, the difference is not very large. This is probably due to the calculation scale. The Census weighting areas, according to which the typologies are classified, cover heterogeneous spaces. Figure 3 shows a part of the city in which there are only areas classified with the Upper and Middle typologies. Along with each hexagon's isolation, Porto Alegre's Municipal
Housing Department (Departamento Municipal de Habitação - DEMHAB) included a mapping of areas with land irregularities. It is precisely these poorer areas (such as Santa Teresa hill and Bom Jesus village) that represent the low isolation points within the larger isolation regions. If they had their typology classification, these neighborhoods would probably be considered Popular, but the aggregation level of the Census data disclosure ends up lumping them together with areas with very different social characteristics.

The alternative to avoiding this problem is to use census tract data, the smallest area of the Census. However, for this level of disaggregation, IBGE releases only a few variables, so, instead of the socio-spatial typologies, which synthesize several variables, the analysis considered only income for the census sector.

Table 2 - Socio-spatial typology monthly isolation average

$6 / 7 / 2020$ to $10 / 24 / 2020$

\begin{tabular}{|c|c|c|c|c|c|c|}
\hline & & $\begin{array}{c}\text { June } \\
\%\end{array}$ & $\begin{array}{c}\text { July } \\
\%\end{array}$ & $\begin{array}{c}\text { August } \\
\%\end{array}$ & $\begin{array}{c}\text { September } \\
\%\end{array}$ & $\begin{array}{c}\text { October } \\
\%\end{array}$ \\
\hline \multirow{3}{*}{ Weekdays } & Popular & 37.7 & 40.7 & 37.1 & 34.9 & 33.0 \\
\hline & Middle & 39.0 & 42.1 & 38.5 & 35.7 & 33.7 \\
\hline & Upper & 43.4 & 46.7 & 43.2 & 39.8 & 37.5 \\
\hline \multirow{3}{*}{$\begin{array}{l}\text { Saturdays, } \\
\text { Sundays and } \\
\text { holidays }\end{array}$} & Popular & 48.1 & 49.9 & 47.2 & 47.9 & 44.1 \\
\hline & Middle & 49.7 & 51.6 & 48.0 & 48.9 & 44.2 \\
\hline & Upper & 53.3 & 55.7 & 51.5 & 51.9 & 47.1 \\
\hline \multirow{3}{*}{ Total } & Popular & 41.4 & 43.1 & 40.3 & 38.8 & 36.7 \\
\hline & Middle & 42.7 & 44.5 & 41.6 & 39.7 & 37.2 \\
\hline & Upper & 46.9 & 49.0 & 45.8 & 43.4 & 40.7 \\
\hline
\end{tabular}

Raw data source: Inloco (2020). 
Figure 3 - Presence of villages and Social Isolation Index

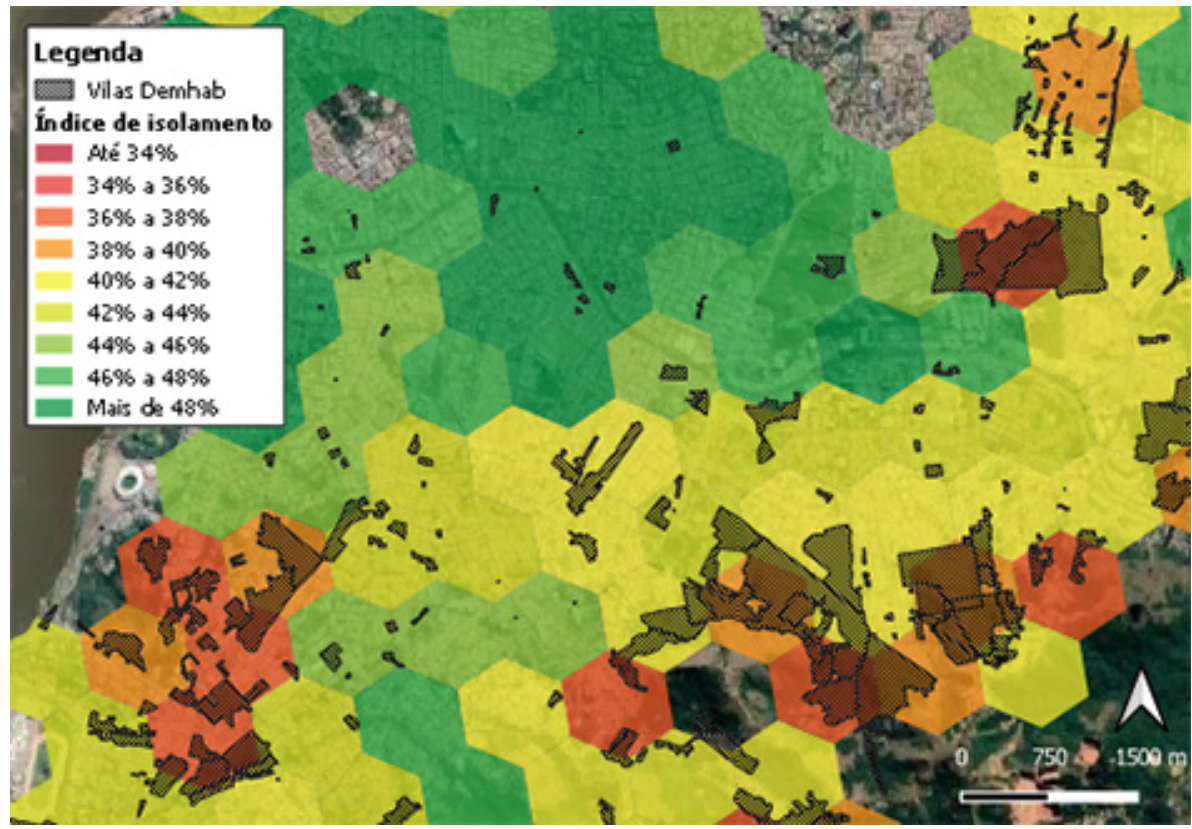

Source: Inloco (2020), ObservaPOA (2017), and Google Satellite.

Social Isolation Index and census tracts by income range

To calculate the social isolation per census sector, the sectors were aggregated by the per capita income range, calculated from the "monthly nominal income average value of people aged 10 years or more (with and without income)" variable. Six bands were defined according to the minimum wage value in force in the year the Census was carried out. The results are presented in Table 3 .
The Social Isolation Index grows as the census sector average income increases. It is a curious fact the difference between the two largest ranges. On weekdays, their isolation is almost equal, which indicates that from 5 minimum wages on, the income increase no longer differentiates those who can work at home. On weekends, the isolation of above10-minimum wage income areas presents a lower index. That is, among the richest, the probability of leaving home to work is lower, but to go for a walk is higher. 
Table 3 - Average monthly isolation by income range of the census sectors

$6 / 7 / 2020$ to $10 / 24 / 2020$

\begin{tabular}{l|c|c|c|c}
\hline & $\begin{array}{c}\text { Weekdays } \\
\%\end{array}$ & $\begin{array}{c}\text { Saturdays } \\
\%\end{array}$ & $\begin{array}{c}\text { Sundays and holidays } \\
\%\end{array}$ & $\begin{array}{c}\text { Total } \\
\%\end{array}$ \\
\hline Up to 1 MW & 36.5 & 41.5 & 51.5 & 39.7 \\
\hline From 1 to 2 MW & 37.1 & 42.4 & 52.4 & 40.4 \\
\hline From 2 to 3 MW & 39.2 & 44.3 & 54.0 & 42.4 \\
\hline From 3 to 5 MW & 41.5 & 46.4 & 55.9 & 44.6 \\
\hline From 5 to 10 MW & 43.3 & 47.8 & 56.8 & 46.1 \\
\hline Above 10 MW & 43.4 & 46.7 & 55.4 & 45.9 \\
\hline
\end{tabular}

Raw data source: Inloco (2020) and IBGE (2011).

Considering the entire period analyzed, the average isolation of sectors with income from 5 to 10 minimum wages was $6.4 \%$ higher than those with income up to half a wage. The distance is the largest among the three socio-spatial typologies, but, once again, the scale problem may have underestimated these differences. The census tracts represent a small area and thus tend to be more homogeneous than the weighted areas. However, the measurement of isolation is still done by hexagons that are about 630,000 $\mathrm{m}^{2}$. Figure 4 exemplifies the problem with an isolation polygon located on the border of the Chácara das Pedras, Jardim Europa, and Vila Jardim neighborhoods. It has census sectors in all six income ranges. To calculate the average isolation of each band, it was considered that all the sectors had isolation of $41 \%$, the hexagon average. However, each small area within this one must have a different isolation rate.
To solve this problem, which happened in several regions of the city, it was created a model, which considers that each income bracket has an (unknown) average isolation rate and that the index of each polygon (that is known) can be seen as a linear combination of these rates, weighted by the area that the census sectors of per capita income bracket occupy within the polygon. For this purpose, it was performed a multiple linear regression, in which the average isolation for the analyzed period of each of the 341 hexagons is explained by the percentage of its area covered by the census sectors of each income band plus an error. To test the location effect, it was included in the regression, a variable that measures the Euclidean distance - in kilometers - from each hexagon's centroid to the Porto Alegre City Hall, located in the Historic Center neighborhood.

All variables were significant at the $1 \%$ level and the result can be interpreted as follows: the intersection represents the 
Figure 4 - Example of census sectors by income and isolation polygon

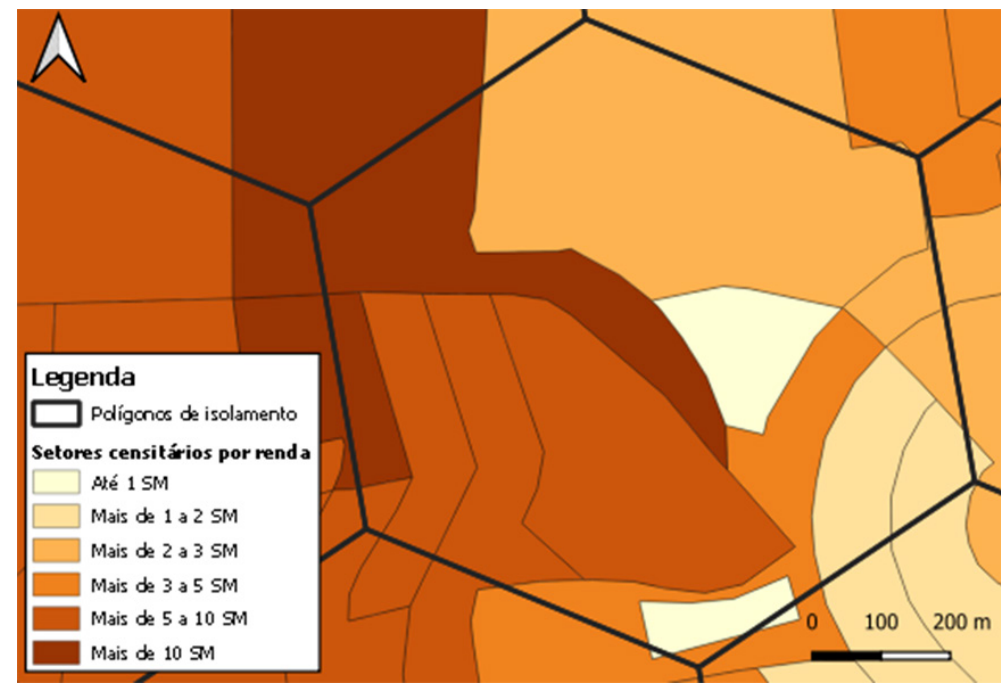

Raw data source: IBGE (2011).

Chart 2 - Regression Results

\begin{tabular}{|l|c|c|}
\hline & Coefficients & value-P \\
\hline Intersection & 0.3909 & 0.0000 \\
\hline From 1 to 2 MW & 0.0255 & 0.0015 \\
\hline From 2 to 3 MW & 0.0376 & 0.0000 \\
\hline from 3 to 5 MW & 0.0781 & 0.0000 \\
\hline From 5 to 10 MW & 0.0959 & 0.0000 \\
\hline Above to 10 MW & 0.0559 & 0.0079 \\
\hline City Hall distance & -0.0012 & 0.0011 \\
\hline R-square & 0,5427 & \\
\hline Adjusted R-square & 0,5344 & \\
\hline
\end{tabular}

Source: made by the authors based on Inloco (2020) and IBGE (2011) data. 
expected isolation rate for an area with an average income below one minimum wage if it were located in downtown Porto Alegre. The other coefficients show the increase in expected isolation for each 1-unit growth of the variables. As the variables represent the percentage of income range in the region, 1 unit means $100 \%$ of the area formed by census sectors of that range. That is, the estimated isolation for areas with income between 1 and 2 minimum wages is $0.3909+0.0255=41.64 \%$.

The range between 5 and 10 minimum wages is the one that presents the largest isolation, with $9.59 \%$ above the base. Moreover, regardless of income, for each kilometer away from City Hall, the isolation drops 0.12 percentage points. This means that more distant areas tend to have lower isolation than central areas, even if they are in the same income bracket. However, since income is not equally distributed in the territory and most outlying areas are inhabited by low-income populations, the combined income and distance coefficients result in an even larger difference in isolation between social groups. The model also made more explicit the difference between the highest income brackets, indicating that in regions inhabited by people with incomes above 10 minimum wages, the social distance is being less respected, even if the financial conditions of these people allow isolation.

Finally, it is important to notice that the model, although significant, only explains $54 \%$ of the isolation variations. There are, therefore, other important factors that influence the index besides income and distance from downtown that are not being considered in the model.

\section{Social Isolation Index in the municipal Participative Budget regions}

At last, it was calculated the average isolation in the 17 regions of Porto Alegre's Participatory Budget, as well as it was made a comparison with the Human Development Index (HDI) ${ }^{6}$ of each region. The results are presented in Table 4 and Figure 5.

Although it appears in the table, the Islands' region will not be considered in the analysis. As it can be seen in Graph 2, it has a completely different pattern from the others. This is because the occupation of this region is not very high, making it difficult to calculate the isolation rate, since there is not enough data. Only one polygon in the region presented information for the days of the analyzed period, which is located in an area of above-average income for the region, which explains the relatively high isolation, despite the low HDI of the whole region, that is, the result does not reflect the reality of the region. On the other hand, the other regions had a minimum of 10 polygons for the calculation of their isolation.

The two PB regions with the highest isolation rate are exactly the ones with the highest HDI: Downtown and Northwest. At the other extreme, the lowest isolation was found in Restinga and the Northeast region, both with human development indexes among the lowest in the city. Considering the 16 regions analyzed, the correlation between the isolation rate and the HDI was 0.91, which shows that the two variables are highly related. 
Table 4 - Social isolation and HDI in the regions of municipal Participative Budget

\begin{tabular}{l|c|c|c|c|c}
\hline \multirow{2}{*}{} & \multirow{2}{*}{ HDI } & \multicolumn{3}{|c}{ Average isolation from 6/7/20 to 10/24/20 } \\
\cline { 3 - 6 } & & $\begin{array}{c}\text { Week days } \\
\%\end{array}$ & $\begin{array}{c}\text { Saturdays } \\
\%\end{array}$ & $\begin{array}{c}\text { Sundays and } \\
\text { holidays - \% }\end{array}$ & $\begin{array}{c}\text { Total } \\
\%\end{array}$ \\
\hline 1 - Humaitá-Navegantes & 0.765 & 38.3 & 43.5 & 53.2 & 41.5 \\
\hline 2 - Northwest (Noroeste) & 0.890 & 41.7 & 46.5 & 55.4 & 44.6 \\
\hline 3 - East (Leste) & 0.777 & 39.2 & 44.1 & 53.9 & 42.4 \\
\hline 4 - Lomba do Pinheiro & 0.683 & 38.0 & 43.4 & 53.6 & 41.4 \\
\hline 5 - North (Norte) & 0.729 & 37.3 & 42.5 & 52.6 & 40.6 \\
\hline 6 - Northeast (Nordeste) & 0.638 & 35.6 & 40.6 & 50.2 & 38.7 \\
\hline 7 - Partenon & 0.764 & 39.1 & 44.7 & 53.6 & 42.3 \\
\hline 8 - Restinga & 0.685 & 35.6 & 40.1 & 50.3 & 38.6 \\
\hline 9 - Glória & 0.733 & 36.9 & 43.1 & 54.2 & 40.7 \\
\hline 10 - Cruzeiro & 0.747 & 38.2 & 43.0 & 53.1 & 41.3 \\
\hline 11 - Cristal & 0.809 & 39.7 & 45.2 & 54.2 & 42.9 \\
\hline 12 - South-Central (Centro Sul) & 0.797 & 38.7 & 43.8 & 53.6 & 41.9 \\
\hline 13 - Far South (Extremo Sul) & 0.714 & 35.9 & 40.8 & 50.9 & 39.1 \\
\hline 14 - Baltazar's Axl (Eixo Baltazar) & 0.779 & 37.1 & 42.3 & 52.3 & 40.4 \\
\hline 15 - South (Sul) & 0.843 & 39.8 & 44.4 & 54.3 & 42.8 \\
\hline 16 - Downtown (Centro) & 0.935 & 44.6 & 49.0 & 57.7 & 47.4 \\
\hline 17 - Islands (Ilhas) & 0.659 & $(42.6)$ & $(50.3)$ & $(62.1)$ & $(46.9)$ \\
\hline
\end{tabular}

Raw data source: Inloco (2020) and ObservaPOA (2015).

Figure 5 - Social Isolation Index in municipal Participative Budget regions (average value between 6/7/2020 and 10/24/2020)

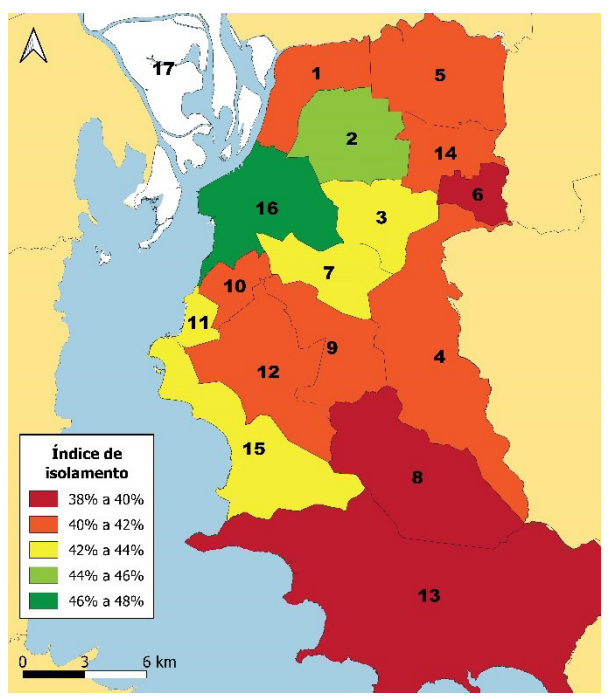

Raw data source: Inloco (2020). 
Graph 2 - Social isolation and HDI in the municipal Participative Budget regions

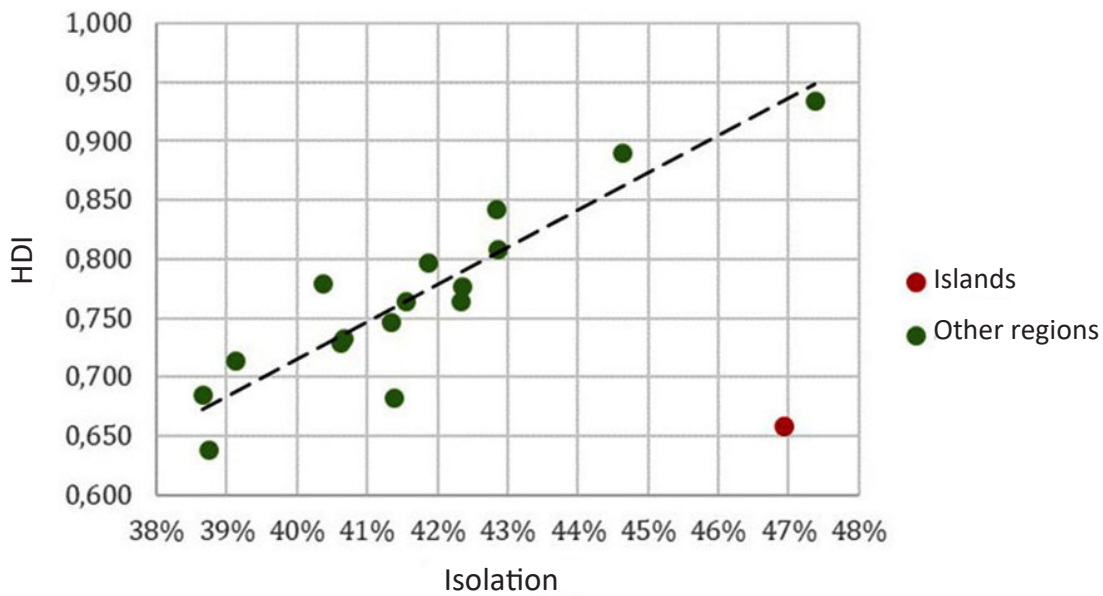

Raw data source: Inloco (2020) and ObservaPOA (2015).

Despite the limitations of the data and the lag of using a census conducted a decade ago, it is clear that the spatial distribution of the level of isolation in Porto Alegre during the pandemic is not neutral. The possibility of exercising the distancing recommended by health authorities is unequally distributed in the territory, and this unequal distribution is related to factors such as work, income, and development of each region.

\section{Final considerations}

One of the big controversies during the pandemic that hit the world in 2020 was the false choice that should be made between "saving lives" or "saving the economy." The supposed economic supporters argued that no distancing measures were necessary and that people should go back to work. In general, this defense was made by the business community, which often did not bother to hide that the lives in question were not their own. The speech of the president of XP Investimento on May 5, 2020, trying to minimize the pandemic situation, is symbolic: "Following a few of our numbers, I would say that Brazil is doing well. Our curves are not so exponential yet we have been managing to flatten. [...] The peak of the disease has already passed when we analyze the middle class, upper-middle-class" (Moura, 2020). At the time, Brazil had already registered about 7,000 deaths. The following months showed that the peak was far from having passed at that moment, even for the social circle of the XP chairman. On the other hand, looking at who had to leave home during the reopening of the economy, it is possible to understand this ruling class's position.

Several studies show that not all Brazilians have the same right to urban mobility. Depending on their living place and the means of transportation available, some have larger access to the city than 
others. One of the surveys that show this is the Access to Opportunities Project (Projeto Acesso a Oportunidades), form Ipea, which analyzed 20 Brazilian cities and showed that "[...] white and high-income population has on average more access to work, health and education opportunities than the black and poor population in all the cities studied" (Pereira; Braga; Serra; Nadalin, 2019). During the pandemic, the same groups that had a larger right to mobility began to have a "right to immobility" to prevent themselves.

By analyzing the case of Porto Alegre, this article showed that, throughout the city, there were found isolation rates that were below the levels recommended by experts to contain the pandemic. However, there are significant differences between city regions. The uneven distribution of isolation is explained by factors such as occupation, income, and development of each region of the city.
Much still needs to be explained about this pandemic. The factors that determine the contagion degree are not clear yet and, in the coming years, it will still be necessary different researches to a better understanding of what is going on. The distribution of cases and deaths by neighborhood, which should be basic information for a study like this, is not correctly disclosed by the government ${ }^{7}$ and deserves to be the focus of new researches.

Any investigation made during the occurrence of the phenomenon has limitations. However, there is enough evidence to believe that social isolation is a relevant factor for the spread of the virus (although it is not the only one) and that the most economically vulnerable people are the ones who are having a larger exposure to the disease. Therefore, in the false dichotomy between health and economy, both are hitting the same groups harder.

\section{[I] https://orcid.org/0000-0003-3558-802X}

Secretaria de Planejamento, Orçamento e Gestão, Departamento de Economia e Estatística. Porto Alegre, RS/Brasil.

andreaugustin.fee@gmail.com

\section{[II] https://orcid.org/0000-0002-3262-768X}

Universidade Federal do Rio Grande do Sul, Departamento de Geografia, Programa de Pós-Graduação em Geografia. Porto Alegre, RS/Brasil.

paulo.soares@ufrgs.br

Translation: this article was translated from Portuguese to English by Gustavo Suertegaray Saldivar, gsuerte@gmail.com. 


\section{Notes}

(1) The spatial cutout "region" is used, because one of the official divisions of the municipality of Porto Alegre is by "Regions of the Participative Budget", which totalizes 17 regions. The composition by neighborhoods of each of the regions can be seen at: http://www2.portoalegre.rs.gov.br/op/ default.php?reg=2\&p_secao $=5$.

(2) Within this period there was data for every day except June 29.

(3) Inloco did not disclose what this minimum number is.

(4) With the postponement of the 2020 Census due to the pandemic and the threat that it will not even occur in 2021 due to lack of budget, a few alternatives are remaining for this type of study.

(5) It was considered a rainy day, on which the accumulated precipitation between 7 am and $10 \mathrm{pm}$ was at least $1 \mathrm{~mm}$ at the weather station A801 of the National Institute of Meteorology, located in the Jardim Botanico neighborhood.

(6) The HDI was calculated by ObservaPOA in 2015, based on 2010 Census data.

(7) In the spreadsheet released by the Health Department of Rio Grande do Sul State, there is a "neighborhood" field for each confirmed case of Covid-19, but there are several errors in filling it out. Although Porto Alegre has only 94 neighborhoods in the spreadsheet, there appear more than two thousand names of neighborhoods. Worse than the typing errors is the lack of filling in: in March 2021, the month with the most deaths from the pandemic, $70 \%$ of the deaths had no neighborhood information at all.

\section{Referências}

ANS - Agência Nacional de Saúde Suplementar (2020). Dados e Indicadores do Setor. Disponível em: http://www.ans.gov.br/perfil-do-setor/dados-e-indicadores-do-setor. Acesso em: 27 out 2020.

AQUINO, E. M. L. et al. (2020). Medidas de distanciamento social no controle da pandemia de CovID-19: potenciais impactos e desafios no Brasil. Ciência Saúde Coletiva, v. 25, supl. 1, Rio de Janeiro, jun. Disponível em: https://doi.org/10.1590/1413-81232020256.1.10502020. Acesso em: 27 out 2020.

BRASIL (2019). Ministério da Economia. Boletim mensal sobre os subsídios da União: Deduções do Imposto de Renda Pessoa Física (IRPF) de Despesas Médicas. Edição 9, jul. Disponível em: file:///C:/Users/Andr\%C3\%A9/Desktop/Bibliografia\%20covid/09-bolsubsidios_9_v2.pdf. Acesso em: 27 out 2020.

(2020). Ministério da Saúde. Painel coronavírus. Disponível em: https://covid.saude.gov.br. Acesso em: 25 out 2020. 
CNS - Conselho Nacional de Saúde (2020). Saúde perdeu R\$ 20 bilhões em 2019 por causa da EC 95/2016. 28 fev. Disponível em: https://conselho.saude.gov.br/ultimas-noticias-cns/1044saude-perdeu-r-20-bilhoes-em-2019-por-causa-da-ec-95-2016. Acesso em: 27 out 2020.

DEMENECH, L. M.; DUMITH, S. C.; VIEIRA, M. E. C. D.; NEIVA-SILVA, L. (2020). Desigualdade econômica e risco de infecção e morte por COVID-19 no Brasil. Revista Brasileira de Epidemiologia, v. 23, e200095. Disponível em: https://www.scielo.br/scielo.php?script=sci_arttext\&pid=S1415790X2020000100209. Acesso em: 30 out 2020.

GAO, S. et al. (2020). Association of Mobile Phone Location Data Indications of Travel and Stay-at-Home Mandates With COVID-19 Infection Rates in the US. JAMA Network Open, set., v. 3, n. 9, e2020485. Disponível em: https://jamanetwork.com/journals/jamanetworkopen/fullarticle/2770249. Acesso em: 15 set 2020.

HARTMANN, M. (2020). Porto Alegre teve aumento de $50 \%$ em novos casos de coronavírus em um dia. Zero Hora, 20 ago. Disponível em: https://gauchazh.clicrbs.com.br/saude/noticia/2020/08/ porto-alegre-teve-aumento-de-50-em-novos-casos-de-coronavirus-em-um-dia-entenda-omotivo-cke3h5bdb00a5013ggb2flsvv.html. Acesso em: 30 out 2020.

HSIANG, S. et al. (2020). The effect of large-scale anti-contagion policies on the COVID-19 pandemic. Nature 584, pp. 262-267 (2020). Disponível em: https://doi.org/10.1038/s41586-020-2404-8. Acesso em: 23 set 2020.

IBGE - Instituto Brasileiro de Geografia e Estatística (2011). Censo Demográfico 2010: Resultados do Universo: Agregados por Setores Censitários. Disponível em: ftp://ftp.ibge.gov.br/Censos/ Censo_Demografico_2010/Resultados_do_Universo/Agregados_por_Setores_Censitarios. Acesso em: 12 set 2010 .

(2020). Pesquisa Nacional por Amostra de Domicílios - PNAD COVID19. Disponível em: https:// www.ibge.gov.br/estatisticas/investigacoes-experimentais/estatisticas-experimentais/27947divulgacao-mensal-pnadcovid2.html. Acesso em: 28 out 2020.

INLOCO (2020). Índice de isolamento social. Dados para o Brasil e unidades da federação Dados para municípios e polígonos cedidos ao Comitê de Dados do Gabinete de Crise para o Enfrentamento da Epidemia Covid-19 do Estado de Rio Grande do Sul. Disponíveis em: https:// mapabrasileirodacovid.inloco.com.br/pt. Acesso em: 25 out 2020.

JOHNS HOPKINS UNIVERSITY (2020). COVID-19 Dashboard by the Center for Systems Science and Engineering (CSSE) at Johns Hopkins University (JHU). Disponível em: https://coronavirus.jhu. edu/map.html. Acesso em: 27 out 2020.

MAMMARELLA, R.; PESSOA, M. L.; FerReIRA, G. S.; TARTARUGA, I. G. P. (2015). “Estrutura social e organização social do território: Região Metropolitana de Porto Alegre - 1980-2010". In: FEDOZZI, L.; SOARES, P. R. R. Porto Alegre: transformações na ordem urbana. Rio de Janeiro, Letra Capital, Observatório das Metrópoles.

MARINO, A.; MENDONÇA, P.; FOLETTO, L.; BRITO, G.; ROLNIK, R.; SANTORO, P. (2020a). Para combater a covid-19, é preciso entender exatamente onde ela está. LabCidade - Laboratório Espaço Público e Direito à Cidade. Disponível em: http://www.labcidade.fau.usp.br/para-combater-a-covid-19e-preciso-entender-exatamente-onde-ela-esta. Acesso em: 25 out 2020. 
MARINO, A.; KLINTOWITZ, D.; BRITO, G.; ROLNIK, R.; SANTORO, P.; MENDONÇA, P. (2020b). Circulação para trabalho explica concentração de casos de Covid-19. LabCidade - Laboratório Espaço Público e Direito à Cidade. Disponível em: http://www.labcidade.fau.usp.br/circulacao-para-trabalhoinclusive-servicos-essenciais-explica-concentracao-de-casos-de-covid-19. Acesso em: 25 out 2020.

MARINO, A. K.; KOMATSU, B. K.; MENEZES-FILHO, N. (2020). Os impactos das medidas de distanciamento social sobre o crescimento do número de casos e óbitos por Covid no Brasil. Insper Policy Paper, n. 49 , set.

MOURA, J. (2020). Pico de Covid-19 nas classes altas já passou; o desafio é que o Brasil tem muita favela, diz presidente da XP. Folha de S.Paulo. 5 maio. Disponível em: https://www1.folha.uol.com.br/ mercado/2020/05/brasil-esta-indo-bem-no-controle-do-coronavirus-e-pico-nas-classes-altasja-passou-diz-presidente-da-xp.shtml. Acesso em: 27 out 2020.

NATIVIDADE, M. S. et al. (2020). Social distancing and living conditions in the pandemic COVID-19 in Salvador-Bahia, Brazil. Ciência \& Saúde Coletiva, v. 25, n. 9, pp. 3385-3392.

OBSERVAPOA - Observatório da Cidade de Porto Alegre (2015). Cinco regiões do OP de Porto Alegre apresentam IDH abaixo da média nacional. Disponível em: http://www.observapoa.com.br/ default.php?reg=379\&p_secao=17. Acesso em: 15 set 2020.

(2017). Mapa do ObservaPOA identifica as áreas de vulnerabilidade da capital. Disponível em: http://observapoa.com.br/default.php?reg=490\&p_secao=17. Acesso em: 23 ago 2020.

PEREIRA, R. H. M.; BRAGA, C. K. V.; SERRA, B.; NADALIN, V. (2019). Desigualdades socioespaciais de acesso a oportunidades nas cidades brasileiras. Texto para Discussão Ipea, 2535. Brasília, Instituto de Pesquisa Econômica Aplicada. Disponível em: http://repositorio.ipea.gov.br/ bitstream/11058/9586/1/td_2535.pdf. Acesso em: 27 out 2020.

PNUD. FPJ. IPEA (2020). Atlas do Desenvolvimento Humano no Brasil. Disponível em: http://www. atlasbrasil.org.br. Acesso em: 20 out 2020.

RIBEIRO, L. C. Q.; RIBEIRO, M. (orgs.) (2016). Índice de Bem-estar Urbano dos municípios Brasileiros. Rio de Janeiro, Observatório das Metrópoles.

RIO GRANDE DO SUL (2020a). Secretaria de Planejamento, Orçamento e Gestão. RS retoma maior índice de isolamento do país. 16 jul. Disponível em: https://planejamento.rs.gov.br/rs-retomamaior-indice-de-isolamento-do-pais. Acesso em: 28 out 2020.

(2020b). Secretaria Estadual da Saúde. Painel Coronavírus RS. Disponível em: https://ti.saude. rs.gov.br/covid19. Acesso em: 25 out. 2020.

SANTOS, M. (2012). Por uma economia política da cidade. São Paulo, Edusp.

SOROEPI MSP (2020). Inquéritos soroepidemiológicos seriados para monitorar a prevalência da infecção por SARS-CoV-2 no Município de São Paulo. Fase 4. Disponível em: https://www. monitoramentocovid19.org/fase-4. Acesso em: 29 out 2020.

UNDP - United Nations Development Programme (2019). Human Development Report 2019: Beyond income, beyond averages, beyond today: Inequalities in human development in the 21st century. Nova York, Organização das Nações Unidas. Disponível em: http://hdr.undp.org/sites/default/ files/hdr2019.pdf. Acesso em: 27 out 2020. 
UNAFISCO - Associação Nacional dos Auditores Fiscais da Receita Federal do Brasil (2020). Imposto sobre grandes fortunas: definição da arrecadação, alíquota e limite de isenção ideais, perfil dos contribuintes, tabela progressiva e recursos para a crise resultante da pandemia da Covid-19. Nota Técnica Unafisco n. 17/2020. Disponível em: https://unafisconacional.org.br/wp-content/ uploads/2020/09/NT-17-1.pdf. Acesso em: 27 out 2020.

ZHOU, Y.; XU, R.; HU, D.; YUE, Y.; LI, Q.; XIA, J. (2020). Effects of human mobility restrictions on the spread of COVID-19 in Shenzhen, China: a modelling study using mobile phone data. Lancet Digital Health, v. 2, n. 8, E417-E424, ago.

Received: October 30, 2020

Approved: April 9, 2021 
